\title{
Development of Ciprofloxacin-loaded contact lenses using fluorous chemistry
}

\author{
Guoting Qin ${ }^{1, *}$, Zhiling Zhu ${ }^{2}$, Siheng Li $^{2}$, Alison M. McDermott ${ }^{1}$, Chengzhi Cai ${ }^{2, *}$. \\ ${ }^{1}$ College of Optometry, ${ }^{2}$ Department of Chemistry, University of Houston, Houston, TX, 77204 \\ USA \\ * Corresponding authors. \\ E-mail addresses: gqin@ central.uh.edu (G. Qin), cai@uh.edu (C. Cai).
}

\begin{abstract}
In this work, we developed a simple method to load drugs into commercially available contact lenses utilizing fluorous chemistry. We demonstrated this method using model compounds including fluorous-tagged fluorescein and antibiotic ciprofloxacin. We showed that fluorous interactions facilitated the loading of model molecules into fluorocarbon-containing contact lenses, and that the release profiles exhibited sustained release. Contact lenses loaded with fluorous-tagged ciprofloxacin exhibited antimicrobial activity against Pseudomonas aeruginosa in vitro, while no cytotoxicity towards human corneal epithelial cells was observed. To mimic the tear turnover, we designed a porcine eye infection model under flow conditions. Significantly, the modified lenses also exhibited antimicrobial efficacy against Pseudomonas aeruginosa in the ex vivo infection model. Overall, utilizing fluorous chemistry, we can construct a drug delivery system that exhibits high drug loading capacity, sustained drug release, and robust biological activity.
\end{abstract}

\section{Keywords}

Fluorous chemistry, contact lenses, drug delivery, antimicrobial activity

\section{Introduction}

Currently more than $90 \%$ of ophthalmic drugs are delivered in the form of eye drop solutions.[1] However, only 1-7\% of the administered dose is actively absorbed.[2] Therefore, high drug dosage and frequent administration are necessary in order to have a therapeutic effect, which results in undesired toxicity and low patient compliance. In the search for alternative approaches, contact lenses as ocular drug delivery systems have attracted tremendous attention due to high ocular drug availability, less frequent administration, and low drug toxicity, which could potentially provide a more convenient treatment regime and better patient compliance.[38]

The approaches to incorporate drugs into contact lenses have evolved in recent years. Initially, simple immersion of contact lenses in drug solution was tested and found to be insufficient due to its low loading efficiency and fast burst release within the first few minutes, which does not offer significant advantages compared to eye drops.[9-17] In some cases, lens transparency was largely decreased due to drug precipitation.[14] In attempts to overcome these issues, several strategies have emerged, such as molecular imprinting, covalent attachment of drug molecules to contact lenses, plasma treatment of the contact lenses, and delivery of drugs using nanomaterials. Molecular imprinting, a method that creates binding sites within contact 
lenses with high affinity for specific drugs, greatly improved loading and reproducibility.[18-28] A "layer-by-layer" design of contact lenses, $[29,30]$ in which a layer of drugs was sandwiched between two polymeric layers, may offer extended drug release. However, this method is difficult to be incorporated in to the contact lens manufacturing process, and some drugs may lose their biological activity during the process. Plasma treatment, a technology that has been long used to improve the wettability of contact lenses, has shown to desirably slow down the initial burst release of drugs from lenses.[31, 32] However, the plasma conditions have to be carefully controlled as insufficient and aggressive treatments either do not have any effect or have the potential to result in the loss of the drugs' bioactivity. Recently contact lenses have been combined with nano-/micro- scale drug delivery systems such as liposomes,[33] polymeric materials,[15, 27, 30, 34] and micelles[35]. These nano-/micro- scale drug delivery systems offer high drug loading capacity and suitability for nearly any kind of drug by rational design of the system. One recent approach described a polymeric "nanowafer" disk that was fabricated using lithography and loaded with drug into nano-/micro- sized holes, which greatly increased drug loading.[36] Each method has its own advantages in one or two areas, but unfortunately, none to date has provided simple manufacture process, high drug loading efficacy, satisfactory drug release kinetics, and high optical quality after drug incorporation. Furthermore, contact lens wear is associated with high risk of complications such as potentially vision threatening infection and inflammation.[37-42] With the widespread and rapid growth of contact lens wear not only for optical correction but also for purposes such as cosmesis and smart lenses with biosensors[4351], it is essential to make contact lenses safer to wear by equipping them with antimicrobial and anti-inflammatory abilities. To this end, a recent design for safer contact lenses with covalently attached antimicrobial peptide has been tested in laboratory animals and humans.[52] Overall, novel designs of contact lens drug delivery systems are needed to address all the above issues. In this work, we developed a simple yet effective method based on fluorous chemistry to incorporate drugs into contact lenses that has great potential to provide the desirable characteristics of an ideal contact lens drug delivery system.

Fluorous chemistry is based on the unique fluorous interactions with which fluorous-tagged carbon chains are attracted to each other much more than other media.[53-55] These interactions are neither hydrophilic nor hydrophobic. Fluorous interactions have been widely used for antifouling coatings. [56-58] Furthermore, perfluorocarbons are used to enhance oxygen delivery in contact lenses, ultrasound imaging and therapy.[59-64] We have used fluorous interactions for incorporating active groups such as alkynes or carboxylic acids onto various substrate surfaces including contact lens surfaces pre-modified with fluorous chains.[65] The functional molecules such as antimicrobial peptides are then covalently attached to the surface via click chemistry. However, this approach has its limitations. In particular, this approach is a 2-step procedure, and during the covalent attachment step, fluorous molecules are susceptible to dissociation from the surface. To keep the molecules on the surface requires a very strong fluorous interaction, thus limiting its application to contact lenses with a high content of fluorocarbon chains, which is not commonly found in commercial contact lenses. Furthermore, the toxic copper catalysts used for covalent modification of contact lenses may be difficult to remove.

In this work, we overcome the above limitations by attaching a short fluorous tag to the drug molecule. We show that the fluorous-tagged drugs can be easily loaded to common fluorinecontaining contact lenses and the system exhibits a desired release profile.

\section{Methods and Materials}




\subsection{Materials}

Ciprofloxacin, trimethylamine, methylene chloride, heptafluorobutyric acid, perfluoropentanoic acid, fluorescein isothiocyanate (FITC) and perfluoroheptanoic acid were purchased from Sigma-Aldrich (St. Louis, MO) and used without further purification. Pseudomonas aeruginosa strain 19660 was purchased from ATCC. A telomerase transformed human corneal epithelial cell line (hTCEpi) [66] was used for in vitro studies.

\subsection{Synthesis of fluorous-tagged FITC and ciprofloxacin derivatives}

\subsubsection{Synthesis of fluorous-tagged FITC (FITC-F)}

A solution of $1 \mathrm{H}, 1 \mathrm{H}$-perfluorooctylamine $(2 \mathrm{mM}, 10 \mathrm{~mL})$ in ethanol was added dropwise to a stirred solution of Fluorescein isothiocyanate (FITC, $15.57 \mathrm{mg}$ ) in $10 \mathrm{~mL}$ of ethanol at room temperature. The solution was stirred for $24 \mathrm{~h}$, and evaporated under reduced pressure. The residue was purified by silica gel flash chromatography eluted with ethyl acetate/MeOH 9/1 to give FITC-F (22 mg, 93\%) as a green powder. ${ }^{1} \mathrm{H}$ NMR $(500 \mathrm{MHz}$, acetone-d6) $\delta 9.05(\mathrm{~s}, 2 \mathrm{H})$, $7.98-7.89(\mathrm{~m}, 2 \mathrm{H}), 7.26(\mathrm{dd}, J=8.1,7.0 \mathrm{~Hz}, 1 \mathrm{H}), 6.75(\mathrm{~d}, J=2.5 \mathrm{~Hz}, 2 \mathrm{H}), 6.72(\mathrm{~d}, J=4.0 \mathrm{~Hz}$, $1 \mathrm{H}), 6.70(\mathrm{~d}, J=3.5 \mathrm{~Hz}, 1 \mathrm{H}), 6.65-6.64(\mathrm{~m}, 1 \mathrm{H}), 6.63(\mathrm{dt}, J=4.9,1.8 \mathrm{~Hz}, 1 \mathrm{H}), 4.75(\mathrm{dtd}, J=$ 48.0, 16.4, 6.2 Hz, 2H), 4.47 (q, $J=7.2 \mathrm{~Hz}, 1 \mathrm{H}) .{ }^{13} \mathrm{C}$ NMR (126 MHz, Acetone-d6) $\delta 184.39$, $169.11,169.07,160.30,153.35,153.32,153.28,149.98,146.63,141.81,131.30,130.17,130.13$, $130.09,128.40,125.88,125.17,125.12,124.75,119.22,119.07,117.36,116.63,113.30,111.65$, 111.58, 111.55, 103.33, 55.44. ${ }^{19} \mathrm{~F}$ NMR (471 $\left.\mathrm{MHz}, \mathrm{CDCl}_{3}\right) \delta-81.44--81.64(\mathrm{~m}, 3 \mathrm{~F}),-117.09-$ $-117.92(\mathrm{~m}, 2 \mathrm{~F}),-122.23(\mathrm{~s}, 2 \mathrm{~F}),-122.46(\mathrm{~s}, 2 \mathrm{~F}),-123.18(\mathrm{~s}, 2 \mathrm{~F}),-123.94(\mathrm{~s}, 2 \mathrm{~F}),-126.63(\mathrm{td}, J=$ 14.6, 6.9 Hz, 2F). MALDI-TOF-MS m/z: [M] ${ }^{+}$calcd for $\mathrm{C}_{29} \mathrm{H}_{17} \mathrm{~F}_{15} \mathrm{~N}_{2} \mathrm{O}_{5} \mathrm{~S}$ : 790.06; found: 790.10 .

\subsubsection{Synthesis of fluorous-tagged ciprofloxacin derivatives compound 1-4}

Ciprofloxacin $(250 \mathrm{mg}, 0.75 \mathrm{mmol})$ and triethylamine $(139 \mu \mathrm{L}, 1 \mathrm{mmol})$ were stirred in anhydrous methylene chloride $(5 \mathrm{~mL})$ at $0{ }^{\circ} \mathrm{C}$ for $15 \mathrm{~min}$. Heptafluorobutyric acyl chloride (259.8 $\mathrm{mg}, 1.12 \mathrm{mmol}$ ) was added dropwise into the mixture under nitrogen atmosphere. The suspension was stirred at room temperature for $12 \mathrm{~h}$, and evaporated under reduced pressure. The residue was purified by silica gel flash chromatography eluted with ethyl acetate/acetone/dichloromethane (v:v:v $=10: 1: 20)$ to give $\mathbf{1}(173.9 \mathrm{mg}, 33 \%)$ as a white powder. ${ }^{1} \mathrm{H}$ NMR $\left(500 \mathrm{MHz}, \mathrm{CDCl}_{3}\right) \delta 8.73(\mathrm{~s}, 1 \mathrm{H}), 8.01(\mathrm{~d}, \mathrm{~J}=12.7 \mathrm{~Hz}, 1 \mathrm{H}), 7.38(\mathrm{~d}, \mathrm{~J}=7.0 \mathrm{~Hz}, 1 \mathrm{H})$, $3.96(\mathrm{dd}, \mathrm{J}=8.9,4.7 \mathrm{~Hz}, 4 \mathrm{H}), 3.56(\mathrm{~s}, 1 \mathrm{H}), 3.45-3.36(\mathrm{~m}, 4 \mathrm{H}), 1.42(\mathrm{q}, \mathrm{J}=6.6 \mathrm{~Hz}, 2 \mathrm{H}), 1.21(\mathrm{t}$, $\mathrm{J}=5.0 \mathrm{~Hz}, 2 \mathrm{H}) .{ }^{13} \mathrm{C} \mathrm{NMR}\left(126 \mathrm{MHz}, \mathrm{CDCl}_{3}\right) \delta 177.15,166.83,156.47,154.70,152.70,147.81$, $145.03,139.05,120.82,112.95,112.77,108.40,105.50,50.17,49.42,45.95,43.55,35.49,8.43$. ${ }^{19} \mathrm{~F}$ NMR $\left(470 \mathrm{MHz}, \mathrm{CDCl}_{3}\right) \delta-79.58(\mathrm{t}, J=9.5 \mathrm{~Hz}, 3 \mathrm{~F}),-111.46--111.53(\mathrm{~m}, 2 \mathrm{~F}),-121.14--$ $121.21(\mathrm{~m}, 2 \mathrm{~F}),-125.51--125.57(\mathrm{~m}, 2 \mathrm{~F})$. MS (ESI) m/z: $[\mathrm{M}+\mathrm{H}]^{+}$calcd for $\mathrm{C}_{21} \mathrm{H}_{18} \mathrm{~F}_{8} \mathrm{~N}_{3} \mathrm{O}_{4}=$ 528.12; found 528.09.

Compound 2 was similarly obtained in $178.9 \mathrm{mg}, 31 \%$ as a yellow powder. ${ }^{1} \mathrm{H}$ NMR (500 MHz, Acetone-d6) $\delta 8.70(\mathrm{~s}, 1 \mathrm{H}), 7.93(\mathrm{~d}, \mathrm{~J}=13.1 \mathrm{~Hz}, 1 \mathrm{H}), 7.79(\mathrm{~d}, \mathrm{~J}=7.4 \mathrm{~Hz}, 1 \mathrm{H}), 4.06-3.94$ $(\mathrm{m}, 4 \mathrm{H}), 3.88(\mathrm{dd}, \mathrm{J}=7.1,3.5 \mathrm{~Hz}, 1 \mathrm{H}), 3.61-3.52(\mathrm{~m}, 4 \mathrm{H}), 1.48(\mathrm{~d}, \mathrm{~J}=6.0 \mathrm{~Hz}, 2 \mathrm{H}), 1.39-1.30$ 
(m, 2H). ${ }^{13} \mathrm{C}$ NMR (126 MHz, Acetone-d6) $\delta 177.89,166.64,156.59,155.42,153.44,149.00$, $145.87,145.79,140.35,130.20,129.37,127.17,120.96,112.31,112.12,108.59,107.80,50.73$, 50.05, 46.41, 44.04, 36.61, 8.49. ${ }^{19} \mathrm{~F}$ NMR $\left(471 \mathrm{MHz}, \mathrm{CDCl}_{3}\right) \delta-80.86(\mathrm{t}, J=9.8 \mathrm{~Hz}, 3 \mathrm{~F})$, $110.94(\mathrm{t}, J=12.2 \mathrm{~Hz}, 2 \mathrm{~F}),-121.09(\mathrm{dd}, J=12.7,6.9 \mathrm{~Hz}, 2 \mathrm{~F}),-121.86$ (dddd, $J=13.4,10.0,6.7$, $3.4 \mathrm{~Hz}, 2 \mathrm{~F}),-124.50--124.62(\mathrm{~m}, 2 \mathrm{~F})$. MS (ESI) m/z: $[\mathrm{M}+\mathrm{H}]^{+}$calcd for $\mathrm{C}_{22} \mathrm{H}_{18} \mathrm{~F}_{10} \mathrm{~N}_{3} \mathrm{O}_{4}=$ 578.11; found 578.08.

Compound 3 was similarly obtained in $202 \mathrm{mg}, 40 \%$ yield as a pale yellow powder. ${ }^{1} \mathrm{H} \mathrm{NMR}$ $\left(500 \mathrm{MHz}, \mathrm{CDCl}_{3}\right) \delta 8.63(\mathrm{~s}, 1 \mathrm{H}), 7.86(\mathrm{~d}, \mathrm{~J}=12.7 \mathrm{~Hz}, 1 \mathrm{H}), 7.34(\mathrm{~d}, \mathrm{~J}=7.0 \mathrm{~Hz}, 1 \mathrm{H}), 3.93-3.71$ (m, 4H), $3.61-3.51(\mathrm{~m}, 1 \mathrm{H}), 3.47-3.28(\mathrm{~m}, 4 \mathrm{H}), 2.68(\mathrm{dd}, \mathrm{J}=9.6,6.2 \mathrm{~Hz}, 2 \mathrm{H}), 2.49$ (ddd, J = 17.6, 14.4, 7.8 Hz, 2H), $1.40(\mathrm{q}, \mathrm{J}=6.7 \mathrm{~Hz}, 2 \mathrm{H}), 1.20(\mathrm{q}, \mathrm{J}=6.5 \mathrm{~Hz}, 2 \mathrm{H}) .{ }^{13} \mathrm{C} \mathrm{NMR}(126 \mathrm{MHz}$, $\left.\mathrm{CDCl}_{3}\right) \delta 176.91,168.77,167.31,154.64,152.64,147.63,145.46,145.37,139.06,120.04$, 119.98, 112.50, 112.31, 107.84, 105.24, 49.89, 49.36, 45.23, 41.67, 35.53, 26.57, 26.40, 26.23, 24.38, 8.32. ${ }^{19} \mathrm{~F}$ NMR $\left(470 \mathrm{MHz}, \mathrm{CDCl}_{3}\right) \delta-80.62(\mathrm{t}, J=9.9 \mathrm{~Hz}, 3 \mathrm{~F}),-110.68(\mathrm{t}, J=13.4 \mathrm{~Hz}$, $2 \mathrm{~F}),-120.60(\mathrm{~s}, 2 \mathrm{~F}),-121.00(\mathrm{dd}, J=15.2,8.0 \mathrm{~Hz}, 2 \mathrm{~F}),-121.14(\mathrm{dd}, J=12.7,6.9 \mathrm{~Hz}, 2 \mathrm{~F})$, 122.67 (s, 2F), -125.81 - -125.92 (m, 2F). MS (ESI): $[\mathrm{M}+\mathrm{H}]^{+}$calcd for $\mathrm{C}_{22} \mathrm{H}_{22} \mathrm{~F}_{6} \mathrm{~N}_{3} \mathrm{O}_{4}=506.1$, Found 506.2.

Compound 4 was similarly obtained in $203 \mathrm{mg}, 30 \%$ yield as a yellow powder. ${ }^{1} \mathrm{H}$ NMR $\left(500 \mathrm{MHz}, \mathrm{CDCl}_{3}\right) \delta 8.77(\mathrm{~s}, 1 \mathrm{H}), 8.05(\mathrm{~d}, \mathrm{~J}=12.7 \mathrm{~Hz}, 1 \mathrm{H}), 7.38(\mathrm{~d}, \mathrm{~J}=6.6 \mathrm{~Hz}, 1 \mathrm{H}), 3.96(\mathrm{~d}, \mathrm{~J}=$ $11.8 \mathrm{~Hz}, 4 \mathrm{H}), 3.55(\mathrm{~s}, 1 \mathrm{H}), 3.40(\mathrm{~s}, 4 \mathrm{H}), 1.42(\mathrm{~d}, \mathrm{~J}=5.9 \mathrm{~Hz}, 2 \mathrm{H}), 1.22(\mathrm{~s}, 2 \mathrm{H}) .{ }^{13} \mathrm{C}$ NMR $(126$ $\left.\mathrm{MHz}, \mathrm{CDCl}_{3}\right) \delta 177.23,166.85,156.57,154.73,152.73,147.87,144.95,139.08,121.04,120.98$, 113.10, 112.92, 111.37, 110.84, 110.62, 108.56, 105.50, 50.26, 49.45, 46.00, 43.62, 35.48, 8.45. ${ }^{19} \mathrm{~F} \mathrm{NMR}\left(470 \mathrm{MHz}, \mathrm{CDCl}_{3}\right) \delta-85.32(\mathrm{~s}, 3 \mathrm{~F}),-118.30(\mathrm{t}, J=18.5 \mathrm{~Hz}, 2 \mathrm{~F}),-121.05--121.10(\mathrm{~m}$, 2F). MS (ESI): $[\mathrm{M}+\mathrm{H}]^{+}$calcd for $\mathrm{C}_{24} \mathrm{H}_{18} \mathrm{~F}_{14} \mathrm{~N}_{3} \mathrm{O}_{4}=678.1$, Found 678.1.

\subsection{X-ray photoelectron spectroscopy (XPS)}

XPS was used to determine the surface atomic concentrations of $\mathrm{C} 1 s, \mathrm{~N} 1 s, \mathrm{O} 1 s, \mathrm{~F} 1 s, \mathrm{Si} 2 p$ of five types of commercial contact lenses, Comfilcon A, Narafilcon A, Lotrafilcon B, Ocufilcon D, and Delefilcon A. Briefly, lenses were dried in air and cut into pieces of $\sim 5 \times 5 \mathrm{~mm}^{2}$. Each piece was glued onto a stainless steel holder and loaded into a PHI $5700 \mathrm{X}$-ray photoelectron spectrometer, equipped with a monochromatic $\mathrm{Al} K \alpha \mathrm{X}$-ray source $(h v=1486.7 \mathrm{eV})$ at a take-off angle (TOA) of $45^{\circ}$ from the film surface.[67]

\subsection{Loading of molecules into commercial contact lenses}

A list of the commercial contact lenses tested is presented in Table 1. All lenses were air dried and weighed. The weights of Comfilcon A, Narafilcon A, Lotrafilcon B, Ocufilcon D and Delefilcon A lenses are 16.3 $\pm 0.3,15.6 \pm 0.1,20.7 \pm 0.3,15.7 \pm 0.2$, and $21.5 \pm 0.4 \mathrm{mg}$, respectively. Compounds used including FITC-F, FITC, Ciprofloxacin (Cip), fluorous-tagged ciprofloxacin (F-Cip 1-4) are shown in Figure 1. Briefly, commercial lenses were individually immersed in wells of a 24 well plate, each containing $1 \mathrm{~mL}$ PBS solution of FITC-F $(15.6 \mu \mathrm{M})$, FITC $(15.6 \mu \mathrm{M})$, Cip $(100 \mu \mathrm{M})$ or F-Cip $(100 \mu \mathrm{M})$, and incubated for $18 \mathrm{~h}$. Then the lenses were washed with PBS three times for 5 min each. All incubation and wash solutions were collected and the amount of each compound was quantified by spectrophotometry. Standard curves were 
generated with seven standard samples with known concentrations for each individual compound of interest. Specifically, fluorescent compounds FITC and FITC-F were quantified by fluorescence emission at $520 \mathrm{~nm}(\lambda e x=485 \mathrm{~nm})$, and Cip and F-Cip were quantified by absorbance at $275 \mathrm{~nm}$. The amount of each compound in the above collected solutions was then measured with the standard curve. The amount of the compound incorporated into lenses was determined by subtracting the amount in solution from the total amount added initially.

\subsection{Lens transparency after modification}

To determine the transparency of fresh and modified Comfilcon A contact lenses using light transmission, contact lenses were cut into small disks with a diameter of $6 \mathrm{~mm}$ and placed into wells of a UV-transparent 96-well plate, and a wavelength scan from 220 to $800 \mathrm{~nm}$ was conducted using a plate reader (BMG LabTech FLUOstar Omega plate reader, Germany).[28]

\subsection{Time course release of individual compounds from contact lenses}

The modified Comfilcon A lenses were placed into individual wells of a 24 well plate with 1 $\mathrm{mL}$ PBS in each well at room temperature. The PBS solution was replaced with fresh PBS every hour for up to $8 \mathrm{~h}$ or $15 \mathrm{~h}$, or every ten minutes for $2 \mathrm{~h}$ or $6 \mathrm{~h}$. The amount of fluorescent compound released into the collected PBS aliquots was quantified spectrophotometrically based on the above standard curve. The amount of F-Cip released into the collected PBS aliquots was quantified using LC-MS (LCQ Deca XP plus with Surveyor LC, Thermo Fisher, Waltham, MA) with electrospray ionization in positive ion mode. Samples $(5 \mu \mathrm{L}$ each) were loaded onto the analytical column at $200 \mu \mathrm{L} / \mathrm{min}$ (Kinetex XB-C18, $2.1 \times 50 \mathrm{~mm}, 2.6 \mu \mathrm{m}$, Phenomenex) with the following gradient: 0-3 min, 10-75\% (B); 3-7.5 min, 75-91\% (B). The mobile phase consists of (A) water containing $0.1 \%$ formic acid and (B) acetonitrile containing $0.1 \%$ formic acid. Mass spectrometric parameters were as follows: $250^{\circ} \mathrm{C}$ capillary temperature, 45 units sheath gas, 10 units aux gas and $4.5 \mathrm{kV}$ spray voltage. Selective ion monitoring (SIM) was used for detecting FCip 1 and 2, and the quantification was based on the respective standard calibration curve. The detection limit for F-Cip $\mathbf{1}$ and $\mathbf{2}$ is approximately $1.5 \mathrm{pg}$ based on $\mathrm{S} / \mathrm{N}$ ratios.

\subsection{Antibacterial activity of F-Cip}

Laboratory strain Pseudomonas aeruginosa (P. aeruginosa) ATCC 19660 was used to test the antimicrobial activity of modified ciprofloxacin. The strain was inoculated and grown at 37 ${ }^{\circ} \mathrm{C}$ for $18 \mathrm{~h}$. The bacterial suspension $(300 \mu \mathrm{L})$ was added into $100 \mathrm{~mL}$ of nutrient broth and incubated for $2 \mathrm{~h}$ to reach a log growth phase. The resulting bacterial suspension was adjusted to a concentration of $\sim 10^{7} \mathrm{cfu} / \mathrm{mL}$ and $100 \mu \mathrm{l}$ were placed into each well of a 96 well plate. Fifty microliters of F-Cip solution of various concentrations in triplicate were added into the 96 well plate and incubated at $37{ }^{\circ} \mathrm{C}$ for $18 \mathrm{~h}$. The inhibition of microbial growth was determined by measuring the absorbance at $620 \mathrm{~nm}$. The concentration that inhibited $50 \%$ of bacterial growth $\left(\mathrm{IC}_{50}\right)$ was calculated based on absorbance readings from three independent experiments.

\subsection{In vitro antibacterial efficacy of modified contact lenses}


Modified Comfilcon A contact lenses were cut into small disks with a diameter of $6 \mathrm{~mm}$ and placed into wells of a 96 well plate, each with $100 \mu \mathrm{L}$ of bacterial suspension prepared as described above in duplicate. Non-modified lenses taken directly for their packaging were used as control. The plate was incubated at $37{ }^{\circ} \mathrm{C}$ for $18 \mathrm{~h}$. The inhibition of microbial growth was determined by measuring the absorbance at $620 \mathrm{~nm}$. The bacterial inhibition was calculated based on absorbance and the mean values from three independent experiments were plotted.

\subsection{Cytotoxicity of F-Cip and modified contact lenses}

Telomerase modified human corneal epithelial cells were seeded into wells of a 96 well plate with $100 \mu \mathrm{L}$ KGM-2 medium (Lonza Ltd, Switzerland) and incubated at $37{ }^{\circ} \mathrm{C}$ until $\sim 80 \%$ confluence. Ten microliters of ciprofloxacin and fluorous-tagged ciprofloxacin $\mathbf{1}$ and $\mathbf{2}$ were added to the wells with final concentrations of $10,5,2.5,1.25,0.63,0.31,0.16,0.08,0.04,0.02$ $\mu \mathrm{M}$. Cells treated with benzalkonium chloride $(0.05 \%)$ and without any treatment served as controls. The plate was incubated at $37^{\circ} \mathrm{C}$ for $18 \mathrm{~h}$, and cell viability was determined using a cell counting kit-8 assay.

To determine the cytotoxicity of contact lenses, control and modified Comfilcon A lenses were cut into small disks with a diameter of $6 \mathrm{~mm}$ and placed individually into wells of the 96 well plate in duplicate followed by incubation at $37{ }^{\circ} \mathrm{C}$ for $18 \mathrm{~h}$. All lenses were taken out, and cell viability was determined using a cell counting kit-8 assay (Dojindo Molecular Technologies, Inc. Japan).

\subsection{Ex vivo antimicrobial efficacy of modified contact lenses using porcine eyes}

Fresh porcine eyes were purchased from Sioux-Preme Packing Co. (Chicago, IL). The pigs were slaughtered for commercial use and not specifically for the purpose of this study. The eyes were used because their size is similar to that of human eyes, allowing the use of commercially available contact lenses. Upon arrival, eyelids and connective tissues were removed and the porcine eyes were sanitized using 5\% penicillin/streptomycin (Sigma-Aldrich, St. Louis, MO) for $1 \mathrm{~h}$ then washed with PBS three times. Six scratch wounds with a $3 \times 3$ crosshatch pattern and a length of $\sim 1 \mathrm{~cm}$ were created on each cornea using a $27 \mathrm{G}$ needle. The eyes were placed into holders and then $100 \mu \mathrm{L}$ of bacterial solution containing $10^{6} \mathrm{CFU}$ (prepared as in Section 2.7) applied to each cornea. The eyes were left at room temperature in a biosafety cabinet for $5 \mathrm{~h}$. After rinsing with $10 \mathrm{~mL}$ of PBS, control and modified Comfilcon A contact lenses were placed individually onto the eyes. Eyes without any lenses and eyes treated with $0.3 \%$ ciprofloxacin solution every $15 \mathrm{~min}$ for $1 \mathrm{~h}$ served as controls. One eye without scratches but incubated with bacteria served as an additional control. A custom-made apparatus was used to flow culture medium over the surface of the porcine eyes. This apparatus consisted of a fluid reservoir containing DMEM (Life Technologies, Inc. Carlsbad, CA) and small diameter tubing, positioned to create a flow rate of four $25 \mu \mathrm{L}$ drops per min onto individual porcine eyes that were placed directly underneath the tube outlet. The eyes were left for $12 \mathrm{~h}$, and then rinsed with $10 \mathrm{~mL}$ PBS. The corneas were dissected and cut into pieces using a sterile scalpel followed by homogenizing using a LabGen 125 homogenizer (Cole-Parmer, Vernon Hills, IL) for $1.5 \mathrm{~min}$ in $2 \mathrm{~mL}$ PBS. Five hundred microliters of the homogenate solution from each sample was added into individual tubes with $6 \mathrm{~mL}$ nutrient broth, and the mixtures were shaken at $250 \mathrm{rpm}$ at $37{ }^{\circ} \mathrm{C}$ for $10 \mathrm{~h}$. Then $100 \mu \mathrm{L}$ of the bacterial suspension from each sample was taken out and added into a 96-well 
plate in triplicate, and absorbance at $620 \mathrm{~nm}$ was measured and plotted as percentage of bacterial growth inhibition compared to the corneas infected with bacteria but without any treatments.

\subsection{Statistical analysis}

Data are expressed as mean \pm SD. Where applicable, statistical analysis was performed using one-way or two-way ANOVA followed by Tukey's test where significance was found with $\mathrm{p}<$ 0.05 .

\section{Results and Discussion}

\subsection{Loading of FITC-F into contact lenses}

Fluorophore FITC and fluorous-tagged FITC (FITC-F, Figure 1) were used to test loading onto various types of contact lenses, taking advantage of their simple detection by fluorescence. Among the five types of contact lenses tested (Table 1), Comfilcon A, Narafilcon A, and Lotrafilcon B are silicone hydrogels, Ocufilcon D is a conventional hydrogel, and Delefilcon A is made of a mixture of both materials. Notably, among these 5 types of lens materials, Comfilcon A and Lotrafilcon B contain fluorocarbons in their formulations with a surface fluorine content of $3.70 \%$ and $1.05 \%$, respectively (Table 1 ).<smiles>COC(=O)c1cc(NC(=S)NCC(F)(F)C(F)(F)C(F)(F)F)ccc1C1=C2C=CC([O-])=CC2OC2=CC(=O)CC=C21</smiles>

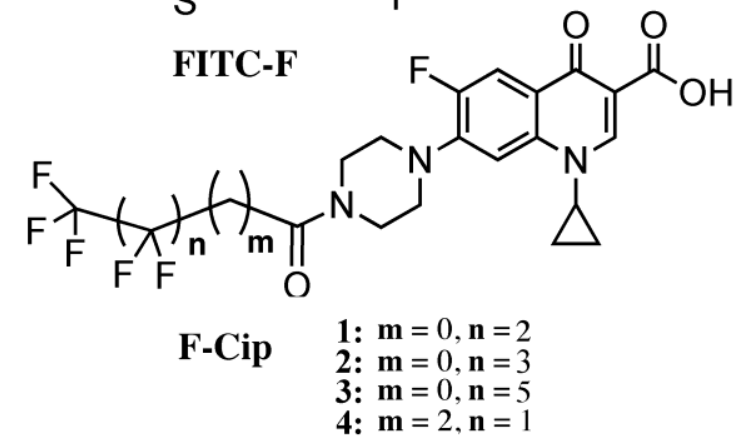

Figure 1. Structures of FITC-F, FITC, and fluorous-tagged ciprofloxacin (F-Cip).

Table 1. Information on the contact lenses tested.

\begin{tabular}{cccccc} 
Trade Name & Biofinity & Air Optix & Biomedics 55 & $\begin{array}{c}\text { Acuvue } \\
\text { TruEye }\end{array}$ & Dailies Total 1 \\
\hline US Adopted Names & Comfilcon A & Lotrafilcon B & Ocufilcon D & Narafilcon A & Delefilcon A \\
\hline
\end{tabular}




\begin{tabular}{cccccc} 
Material & $\begin{array}{c}\text { Silicone } \\
\text { hydrogel }\end{array}$ & $\begin{array}{c}\text { Silicone } \\
\text { hydrogel }\end{array}$ & Hydrogel & $\begin{array}{c}\text { Silicone } \\
\text { hydrogel }\end{array}$ & $\begin{array}{c}\text { Silicone hydrogel } \\
\text { core, non-silicone } \\
\text { hydrogel surface }\end{array}$ \\
\hline Surface fluorine $\mathbf{( \% )}$ & 3.7 & 1.05 & 0 & 0 & 0 \\
\hline
\end{tabular}

As shown in Figure 2, Comfilcon A attracted the greatest amount of FITC-F $(10.1 \pm 0.9 \mathrm{nmol}$ per lens), which was significantly higher than the other four types of lenses. Lotrafilcon B attracted $6.7 \pm 1.9$ nmol FITC-F per lens, which was more than the other three types, and the difference reached statistical significance compared to Ocufilcon D lenses $(1.4 \pm 0.8 \mathrm{nmol} / \mathrm{lens})$. Comfilcon A attracted more FITC-F than Lotrafilcon B, which correlates to the surface fluorine concentration (3.7\% vs $1.05 \%$, Table 1). Furthermore, for Comfilcon A and Lotrafilcon B lenses, the amount of FITC-F loaded onto lenses was significantly more than the amount of FITC, but this was not the case for the other three types of lenses. The amount of FITC-F loaded was $\sim 9$ times greater than the amount of FITC for Comfilcon A lenses $(10.1 \pm 0.9$ vs. $1.1 \pm 1.2$ $\mathrm{nmol} / \mathrm{lens})$, and $\sim 5$ times for Lotrafilcon B lenses (6.7 \pm 1.9 vs. $1.3 \pm 1.3 \mathrm{nmol} / \mathrm{lens})$, respectively. The structural difference between FITC-F and FITC is the fluorocarbon chain (Figure 1). This result demonstrates that the fluorescent dye with a fluorous tag can be efficiently loaded to the widely used commercial, fluorine-containing contact lenses.

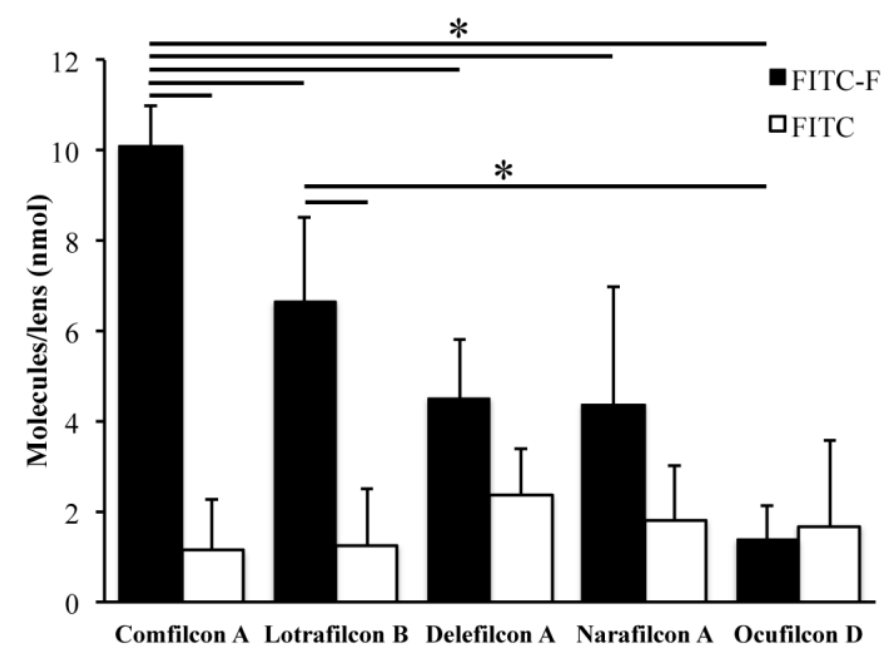

Figure 2. The amount of FITC-F ( $\square)$ and FITC $(\square)$ loaded onto Comfilcon A, Lotrafilcon B, Delefilcon A, Narafilcon A and Ocufilcon D lenses. Data are from at least three independent experiments and are expressed as mean \pm SD. Two-way ANOVA was performed followed by Tukey's test where significance was found. $* \mathrm{p}<0.05$.

\subsection{Release of FITC-F from Comfilcon A lenses}

Comfilcon A lenses were chosen for testing the release profile because they were loaded with the greatest amount of FITC-F. For solution exchange rate of $1 \mathrm{~mL} / \mathrm{h}$, the release of unmodified FITC showed a typical burst release profile, and reached plateau with $\sim 60 \%$ release within the first two hours (Figure 3C). The remaining 40\% was likely on the lenses. Burst release is the major hurdle for clinical applications of current contact lens based drug delivery systems. Significantly, the release of FITC-F showed a sustained profile with a nearly linear release for the first $6 \mathrm{~h}$ with a release rate of $10.5 \%$ per hour (Figure 3A), and reached $\sim 90 \%$ at $15 \mathrm{~h}$. Upon 
increasing the solution exchange rate to $6 \mathrm{~mL} / \mathrm{h}$, as expected, the release of unmodified FITC quickly reached plateau within 50 min (Figure 3D). Meanwhile, the release of FITC-F showed a sustained profile with a nearly linear release for the first $120 \mathrm{~min}$ with a release rate of $26.5 \%$ per hour (Figure 3B), and reached plateau at $270 \mathrm{~min}$. These results showed the release rate increased with faster solution exchange rate, which confirms that the release profiles from contact lens drug delivery model systems are dependent on the experimental setup, and care must be taken to compare results from studies with different setups.[68] The reported tear turnover rate $(\sim 100 \mu \mathrm{L} / \mathrm{h})$ in human subjects varies significantly,[69-72] and is much lower than the rates used in our experiment. It should be pointed out that the solution in our experiment was changed hourly while tear turnover in the eye is a continuous process, which could result in a different drug release profile. Therefore, it is not feasible to predict the release profile of this system in vivo only based on the solution exchange rates.

The focus of this work is to demonstrate the feasibility of using fluorous chemistry for loading molecules into contact lenses and controlling their release. Overall, our data showed that the release of fluorous-tagged molecules from fluorine-containing lenses exhibited a sustained release profile while non-fluorous-tagged molecules showed a burst release profile. Notably, the structural difference between FITC-F and FITC is the fluorocarbon chain. Therefore, this result demonstrates that fluorous interactions are the driving force in the releasing/retaining of molecules with a fluorous tag from fluorocarbon-containing polymers.

A)

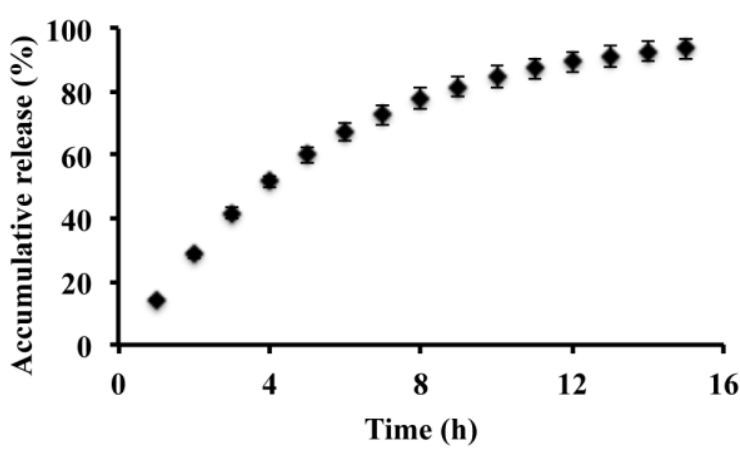

C)

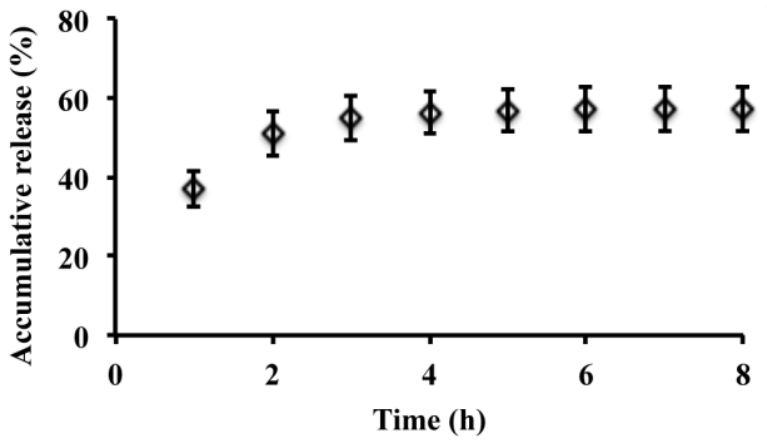

B)

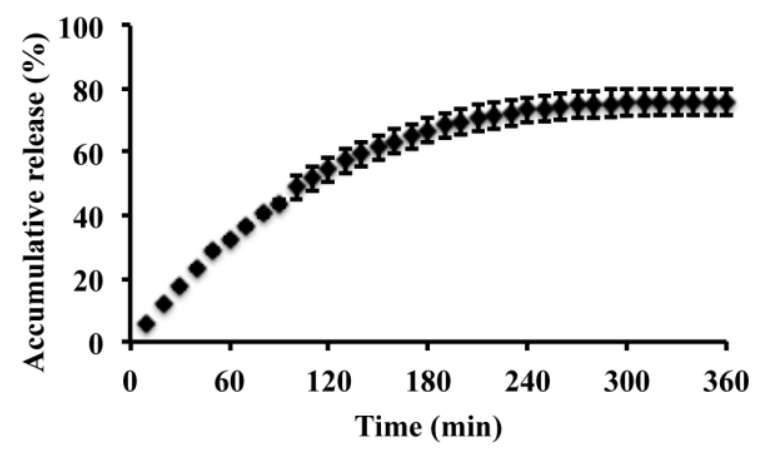

D)

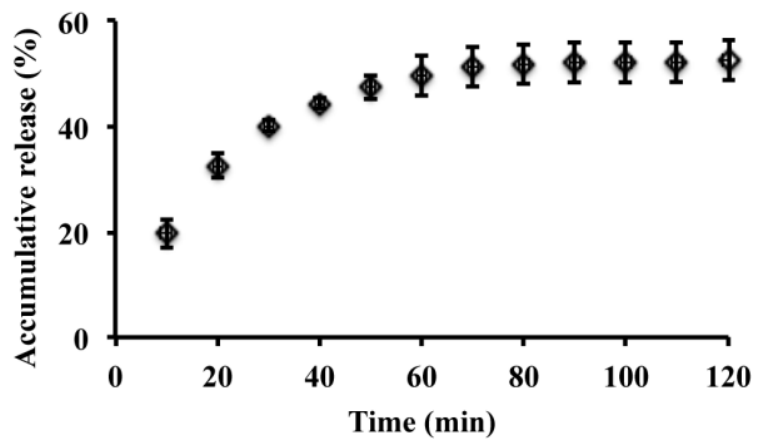

Figure 3. Release of FITC-F (A, B) and FITC (C, D) from Comfilcon A lenses with a solution exchange rate of $1 \mathrm{~mL} / \mathrm{h}(\mathrm{A}, \mathrm{C})$ and $6 \mathrm{~mL} / \mathrm{h}(\mathrm{B}, \mathrm{D})$, respectively. Data are expressed as mean \pm $\mathrm{SD}(\mathrm{n} \geq 3)$. 


\subsection{In vitro antimicrobial activity of fluorous tagged ciprofloxacin}

The above results encouraged us to test the feasibility of using this method to load a drug, e.g. antibiotic ciprofloxacin (Cip) in this case, into a contact lens and using it as a drug delivery system. Thus, a series of fluorous-tagged ciprofloxacin (F-Cip, compounds 1-4) molecules were synthesized, differing in the length of the linker (number of $\mathrm{CH}_{2}$ groups) and the number of fluorinated carbons (See Figure 1 for their structures). Table 2 lists the $\mathrm{IC}_{50}$ values of F-Cip 1-4 against $P$. aeruginosa 19660 . The $\mathrm{IC}_{50}$ value of $\mathrm{Cip}$ was $0.13 \mu \mathrm{M}$, which is similar to the reported values in the literature[73]. Compared to Cip, F-Cip with only 3 and 4 perfluorocarbon atoms $(\mathbf{1}$ and 2$)$ showed a higher $\mathrm{IC}_{50}$ value $(0.63-0.69 \mu \mathrm{M})$. The $\mathrm{IC}_{50}$ values of F-Cip 3 and 4 were greater than the highest concentration we tested $(40 \mu \mathrm{M})$, indicating that both lost their antimicrobial activity. The structural difference between F-Cip 1, 2, and $\mathbf{3}$ is the number of fluorinated carbons, which is 3, 4, and 6 respectively. The result indicated that the longer the fluorinated carbon chain, the less was its antimicrobial efficacy against $P$. aeruginosa 19660. The attachment of a fluorocarbon chain to Cip may undermine the drug's mechanism of action by decreasing its ability to penetrate bacterial cell membrane and/or binding to its target due to the unique properties of fluorocarbons (i.e. neither hydrophilic nor hydrophobic), therefore, the longer the chain, the larger the effect. Furthermore, although F-Cip $\mathbf{4}$ has two fluorinated carbons, it also has two extra carbons between the fluorinated carbon chain and its parent compound Cip, which negatively affected its antimicrobial activity. The above brief screening identified compounds $\mathbf{1}$ and $\mathbf{2}$ as the lead compounds, which were used in subsequent studies.

Table 2. $\mathrm{IC}_{50}$ values of fluorous-tagged ciprofloxacin (F-Cip) and Cip against pseudomonas aeruginosa (PA) ATCC 19660. ( $\mathrm{n} \geq 3$ )

\begin{tabular}{cccc}
\hline No. & No. of $\mathbf{C H}_{\mathbf{2}}$ groups & No. of fluorocarbons & $\mathbf{I C}_{\mathbf{5 0}}(\boldsymbol{\mu M})$ \\
\hline $\mathbf{1}$ & 0 & 3 & $0.63 \pm 0.15$ \\
\hline $\mathbf{2}$ & 0 & 4 & $0.69 \pm 0.62$ \\
\hline $\mathbf{3}$ & 0 & 6 & $>40$ \\
\hline $\mathbf{4}$ & 2 & 2 & $>40$ \\
\hline Cip & & & $0.13 \pm 0.035$ \\
\hline
\end{tabular}

\subsection{Cytotoxicity of F-Cip}

The cytotoxicity of 1, $\mathbf{2}$ and Cip was tested against a telomerase modified human corneal epithelial cell line.[66] Cells exhibited $\sim 100 \%$ viability after incubation with F-Cip 1 and 2, and Cip with concentrations up to $10 \mu \mathrm{M}$ compared to cells without any treatment. Benzalkonium chloride is known to be cytotoxic [74-76] and killed $\sim 100 \%$ cells and served as control. There was no significant difference among Cip, $\mathbf{1}$ and 2, indicating that modification of Cip with a fluorous tag did not change its cytotoxicity. 


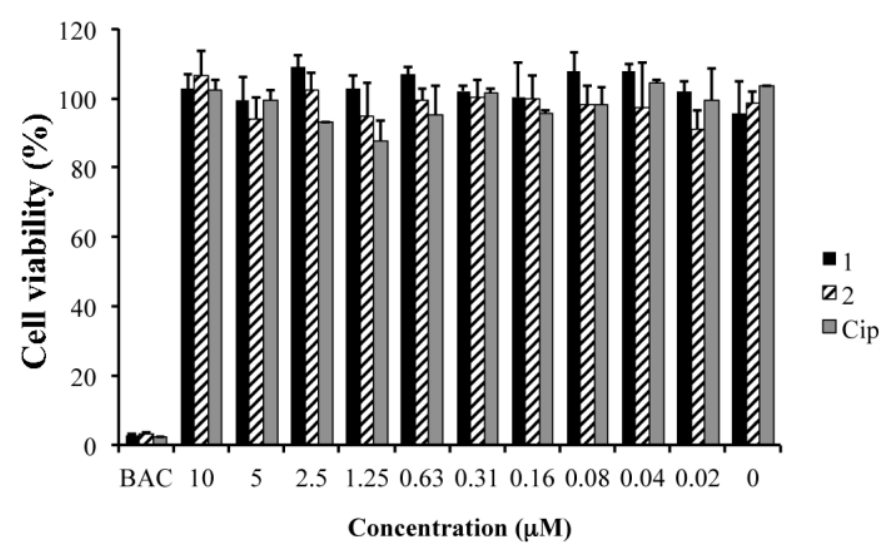

Figure 4. Cytotoxicity of F-Cip 1, 2 and Cip against human telomerase corneal epithelial cells (hTCEpi) with a series of concentrations. BAC: benzalkonium chloride as control. Data are expressed as mean $\pm \mathrm{SD}(\mathrm{n}=3)$.

\subsection{Loading of F-Cip into Comfilcon A lenses}

As Comfilcon A lenses present the greatest amount of fluorine in the formulation, this type of lens was used for the loading experiment of F-Cip. As shown in Figure 5, the amount of 1, 2, 3, and 4 loaded onto contact lenses was $67.96 \pm 11.50,68.72 \pm 5.28,108.36 \pm 5.95$, and 83.31 \pm $8.33 \mathrm{nmol} / \mathrm{lens}$, which was approximately 19, 19, 30, and 23 times more than the amount of Cip loaded on the lenses $(3.56 \pm 4.51 \mathrm{nmol} / \mathrm{lens})$, respectively. There were no statistically significant differences for the loading of the F-Cip 1, 2, and $\mathbf{4}$ onto the contact lenses; however, all of them were significantly higher than the amount of Cip. This result demonstrates that the presence of even a short fluorous tag on the molecule greatly enhances its immobilization onto the fluorocarbon-containing contact lenses. The amount of $\mathbf{3}$ loaded on lenses was significantly more than that of $\mathbf{1}, \mathbf{2}$, and $\mathbf{4}$, demonstrating that longer fluorocarbon chain (i.e. stronger interactions between molecules and the lens) facilitated the loading onto lenses.

It is also remarkable that after modification, the lenses maintained their transparency. As shown in Figure 6, within the visible light range $(350-750 \mathrm{~nm})$, the light transmission of modified lenses remained $\sim 100 \%$ compared to fresh lenses without modification. Therefore, the current simple method has addressed the previously reported issue of loss of transparency of ciprofloxacin-loaded lenses that often exhibited precipitates [14]. 


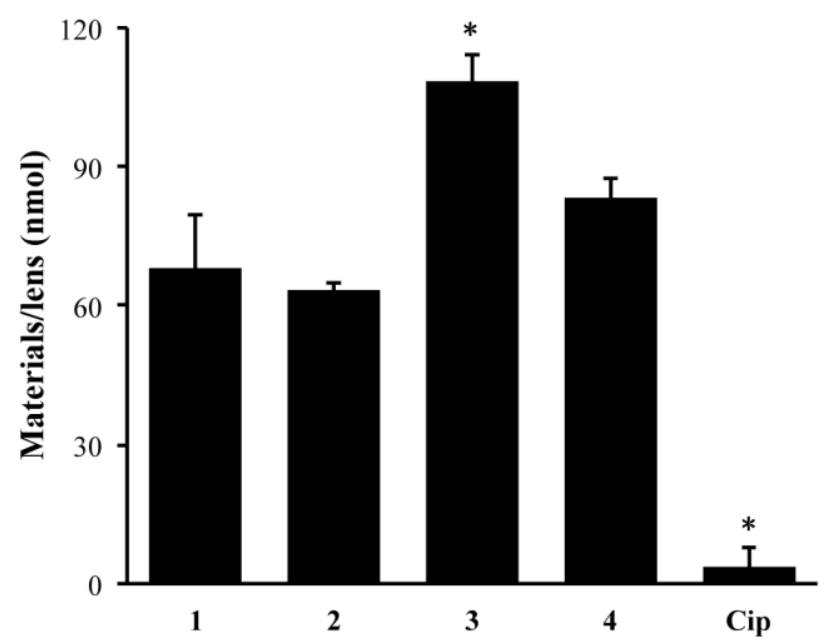

Figure 5. The amount of F-Cip and Cip loaded onto Comfilcon A lenses. Data are from three independent experiments and are expressed as mean \pm SD. One-way ANOVA was performed followed by Tukey's test where significance was found. *p $<0.05$.

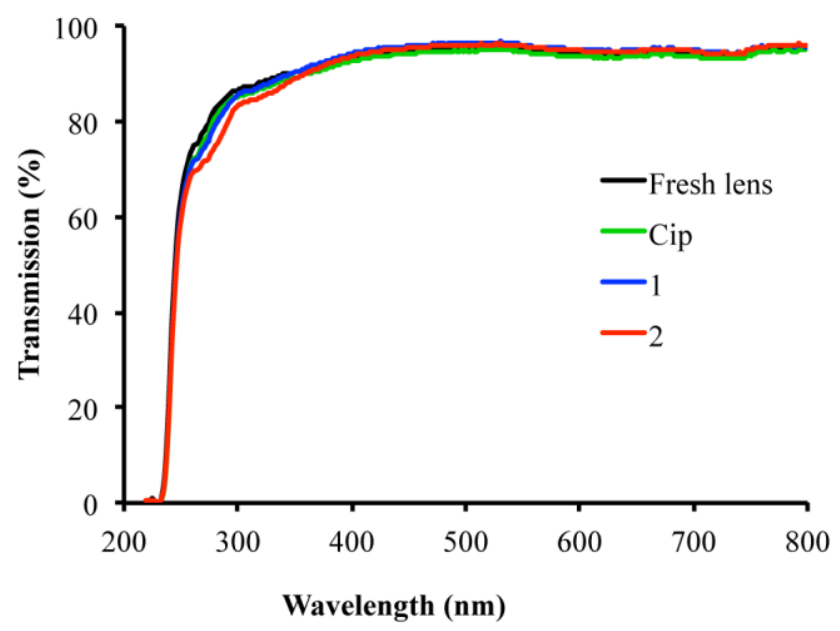

Figure 6. Lens transparency within a wavelength range of 220-800 nm. Fresh lens: black line; Cip: Comfilcon A lenses loaded with ciprofloxacin, green line; 1: Comfilcon A lenses loaded with F-Cip 1, blue line; 2: Comfilcon A lenses loaded with F-Cip 2, red line.

\subsection{Release of F-Cip from Comfilcon A lenses}

Figure 7 shows the release profile of F-Cip 1, 2, and Cip from Comfilcon A lenses over a period of $8 \mathrm{~h}$ with a solution exchange rate of $1 \mathrm{~mL} / \mathrm{h}$. Cip exhibited a typical burst release profile, that is, most release occurred within the first hour and no more release after $3 \mathrm{~h}$. The plateau was reached at $\sim 60 \%$ release, and the remaining $40 \%$ were likely on the lenses. Significantly, both F-Cip $\mathbf{1}$ and $\mathbf{2}$ exhibited a sustained release profile that was very similar to the release profile of FITC-F as shown in Figure 3. Although the percentage release of F-Cip $\mathbf{1}$ and $\mathbf{2}$ within the $8 \mathrm{~h}$ period was lower than that of Cip, the amount of F-Cip released was 6 times of that of Cip because the amount of F-Cip loaded onto lenses ( $68 \mathrm{nmol} / \mathrm{lens})$ was much more than 
that of Cip $(3.56 \pm 4.51 \mathrm{nmol} / \mathrm{lens})$ as shown in Figure 5. The release profiles of $\mathbf{1}$ and $\mathbf{2}$ were very similar indicating that only one $\mathrm{CF}_{2}$ group difference in the structures of these two molecules may not affect the overall fluorous interactions between F-Cip and contact lenses, which was also supported by the comparable amounts of $\mathbf{1}$ and $\mathbf{2}$ loaded onto Comfilcon A lenses.

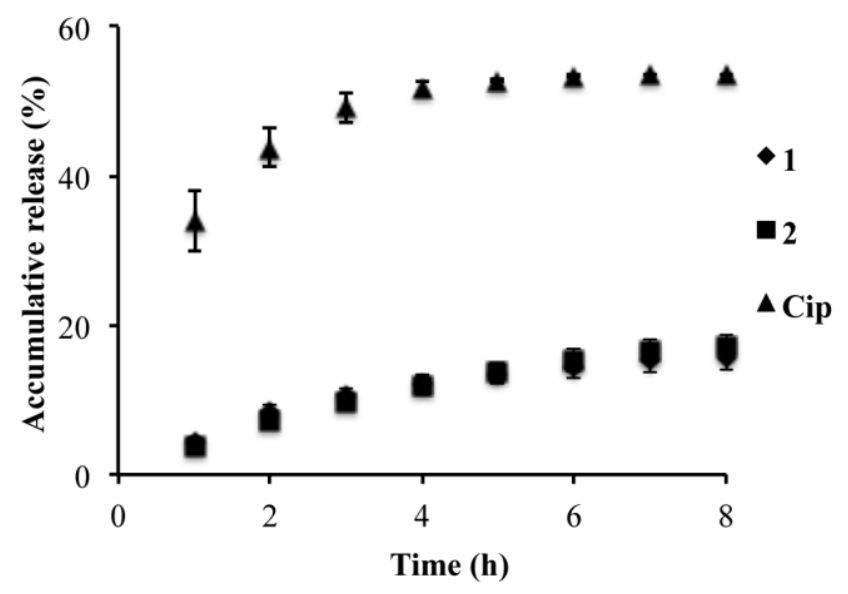

Figure 7. Release of $\mathbf{1}(\diamond), \mathbf{2}(\boldsymbol{\square})$ and Cip ( $\mathbf{\Delta})$ from Comfilcon A lenses over a course of $8 \mathrm{~h}$. Data are expressed as mean \pm SD. $(n=3)$

\subsection{In vitro antimicrobial activity of F-Cip-loaded contact lenses}

The antimicrobial activity of $\mathbf{1}$ - and $\mathbf{2}$ - as well as Cip-loaded Comfilcon A lenses was tested against $P$. aeruginosa 19660. As shown in Figure 8, the lenses loaded with $\mathbf{1}$ and $\mathbf{2}$ exhibited $99.3 \%$ and $93.6 \%$ growth inhibition, which was significantly higher than the $35.2 \%$ by Cip loaded lenses. Although 1 and 2 exhibited $\mathrm{IC}_{50}$ values that were $\sim 5$ times higher than ciprofloxacin (Table 2), the amount of $\mathbf{1}$ and $\mathbf{2}$ loaded onto Comfilcon A lenses was 19 times greater than that of Cip (Figure 5), which may account for the significantly higher efficacy of 1and 2-loaded lenses than Cip-loaded lenses. It is worth noting that in vivo bacteria are also partially cleared from the eye with the continuous tear turnover, which may present a less challenging condition compared to the experimental condition tested here in which bacteria were maintained in nutrient broth without other clearance mechanisms. Therefore, it is significant that this drug-loaded delivery system exhibited nearly complete killing of bacteria under such demanding conditions.

The performance of a drug delivery system is also dependent upon the drug release profile from contact lenses because the released drug has to reach a threshold concentration over a desired period of time. As tear clearance is a continuous process in the eye, the release of drugs from contact lenses needs to be fast enough to overcome the clearance. This requirement is challenging for many drug delivery systems as there would be only a very small portion of drug, if any, to be released after their short burst release period, thus no antimicrobial activity would be observed. To mimic the in vivo conditions, we designed an ex vivo porcine eye infection model to test the antimicrobial efficacy of the modified contact lenses with a flow of culture medium representing tear turnover (See section 3.9). 


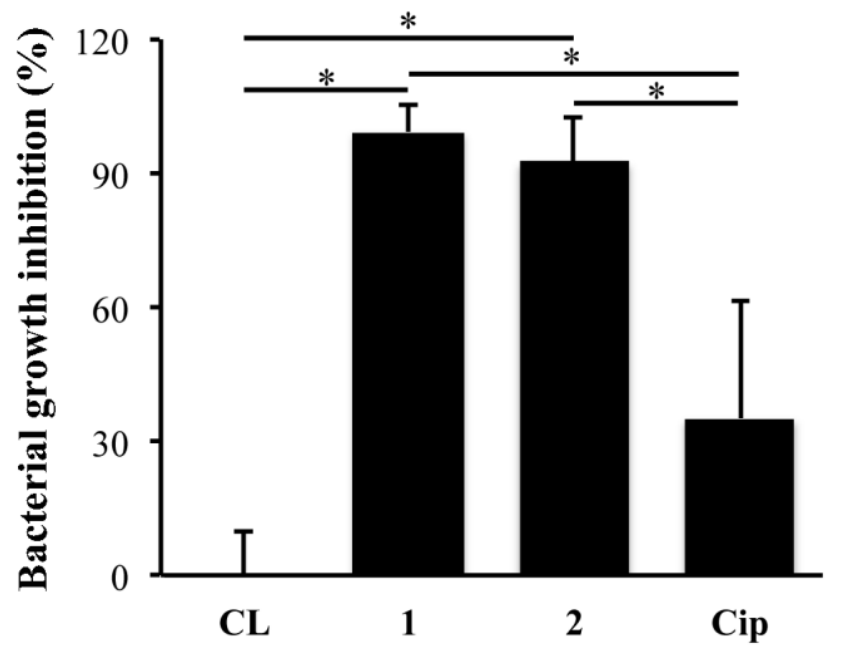

Figure 8. Antimicrobial activity of F-Cip $\mathbf{1}$ and $\mathbf{2}$ and Cip loaded Comfilcon A lenses against $P$. aeruginosa 19660. Data are from three independent experiments expressed as mean $\pm \mathrm{SD}$. Oneway ANOVA was performed followed by Tukey's test where significance was found. * $\mathrm{p}<0.05$.

\subsection{Cytotoxicity of F-Cip-loaded contact lenses}

The cytotoxicity of 1, $\mathbf{2}$ and Cip loaded lenses was tested against hTCEpi cells. Cells exhibited $\sim 100 \%$ viability after incubation with lenses loaded with F-Cip $\mathbf{1}$ and $\mathbf{2}$, and unmodified Cip compared to cells incubated with untreated lenses, and there was no significant difference among them, indicating that loaded drug did not exhibit a toxic effect on this cell line (Figure 9).

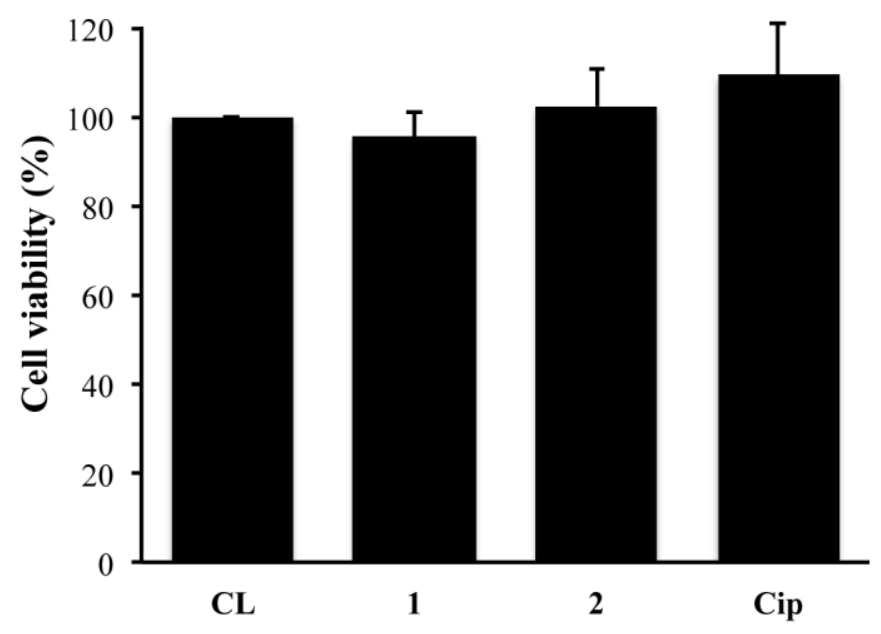

Figure 9. Cytotoxicity of F-Cip and Cip loaded Comfilcon A lenses against hTCEpi cells. Data are from three independent experiments and expressed as mean \pm SD. One-way ANOVA was performed and no significance was found. 


\subsection{Ex vivo infection model and antimicrobial activity of F-Cip-loaded contact lenses}

Porcine eyes have been adopted for studies that test commercial contact lenses due to their similar size and anatomy with human eyes.[77-83] Few studies have been carried out on ocular infections using ex vivo porcine eye models that had a mechanism to mimic the tear turnover.[78, 79, 83] Herein we designed an ex vivo porcine eye infection model, in which culture medium was dripped onto each eye at a rate of four $25 \mu \mathrm{L}$ drops/min to represent the tear turnover in vivo. Using this system, we tested the antimicrobial activity of F-Cip $\mathbf{1}$ and unmodified Cip loaded Comfilcon A lenses against $P$. aeruginosa 19660. Eyes that were infected with bacteria but not exposed to contact lenses served as control. As shown in Figure 10, for eyes with contact lenses modified with F-Cip 1, there was significant bacterial growth inhibition (86.8 $\pm 13.9 \%$ ) compared to the eyes with unmodified lenses (labeled as CL) and lenses modified with Cip, which showed $29.7 \pm 12.7 \%$ and $37.5 \pm 8.2 \%$ bacterial growth inhibition, respectively. This result supported our finding in the in vitro antimicrobial assay. The eyes infected with bacteria and treated with $0.3 \%$ ciprofloxacin solution showed $98.1 \pm 4.3 \%$ bacterial growth inhibition, which was higher than the ones wearing F-Cip modified lenses although this difference did not reach statistical significance $(\mathrm{p}=0.70)$. In clinical practice, a high concentration $(0.3 \%)$ of ciprofloxacin solution is commonly used to treat eye infections and frequent administration is necessary. For example, treatment of relatively mild bacterial conjunctivitis requires one to two drops four times a day, while treatment of sight threatening bacterial ulcers requires drops every fifteen minutes for the first six hours.[84] It should be noted that the amount of ciprofloxacin in the solution that was used for treatment was more than 100 times of the amount of F-Cip 1 $(67.96 \pm 11.50 \mathrm{nmol} / \mathrm{lens}$, see Figure 5), yet these two systems showed a comparable efficacy. Therefore, our approach could significantly reduce the amount of drug needed to treat eye infections. For the eyes without scratch wounds, the number of bacteria detected was much less than that for the control eyes indicating that bacteria did not penetrate the intact corneal epithelium and those that grew on top of the ocular surface were most likely washed away during the washing step. Overall, these results showed that contact lenses loaded with F-Cip exhibited antimicrobial activity in an ex vivo model that represents tear clearance in vivo.

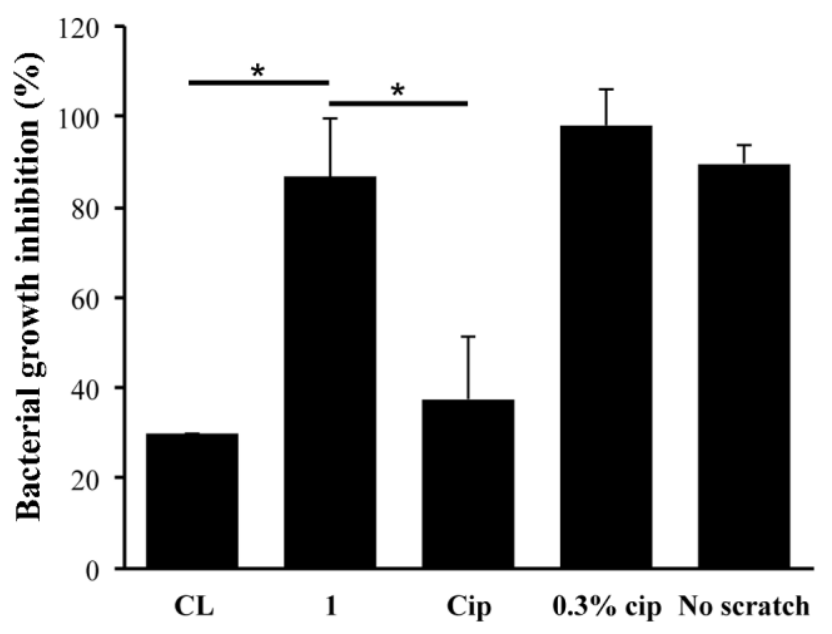

Figure 10. Antimicrobial efficacy of modified Comfilcon A lenses in an ex vivo porcine eye infection model. CL: unmodified lenses. 1: lenses modified with F-Cip 1. Cip: lenses modified 
with Cip. $0.3 \%$ Cip: $0.3 \%$ ciprofloxacin solution administered in the form of eye drops. No scratch: intact porcine eyes. Statistical analysis was performed using one-way ANOVA followed by Tukey's test comparing to 1 where significance was found. $* p<0.05$. $(n=3)$

In summary, we modified both hydrophilic (FITC) and hydrophobic (ciprofloxacin) molecules with fluorinated carbon chains and tested their loading into contact lenses. We found that more F-FITC was loaded onto fluorine-containing Comfilcon A lenses compared to FITC and compared to other non-fluorine-containing contact lenses. Similarly, there was significantly more F-Cip loaded onto Comfilcon A lenses compared to Cip. F-FITC and F-Cip exhibited sustained release from Comfilcon A lenses while unmodified molecules showed typical burst release profiles. Lenses loaded with F-Cip exhibited antimicrobial efficacy against $P$. aeruginosa 19660 in vitro and ex vivo, while not exhibiting cytotoxicity against human corneal epithelial cells.

\subsection{Proposed role of fluorous chemistry}

In our system, the molecular interactions between the molecules and contact lenses consist of hydrophobic, hydrophilic, hydrogen bonding, ionic, and fluorous interactions. As shown in Figure 2 and 5, the loading of fluorous-tagged molecules is much greater than that of their nonfluorous-tagged counterparts, indicating that the fluorous interactions play a significant role. Fluorous interactions are a combination of bonding between fluorinated molecules, which includes several chemical bonding such as F...F, C-F...H, C-F..., , C-F...C=O, etc.,[54] among which the F...F non-covalent interactions that are known to be the strongest attractive force.[85] Extensive theoretical and experimental studies are still ongoing to understand the nature of fluorous interaction force.[85] In general, the fluorous attractive force increases with the number and proximity of the interacting F-atoms in the molecule, and is also affected by the surface dipolar interactions.[86] Attachment of the fluorous tag to the molecules creates the fluorous interactions between the molecules and the fluorous side chains of the contact lens polymers as well as the fluorous interactions among the molecules, thus greatly increases the loading of the fluorous-tagged molecules.

The release data for FITC-F and F-Cip 1 and $\mathbf{2}$ were fitted to the Peppas equation for the first $60 \%$ of the normalized drug release using the following equation $[87,88]$ :

$M_{t} / M_{0}=k t^{n}$

Where $M_{t}$ is the drug released at time $t, M_{0}$ is the total amount of drug released, $k$ is the rate constant, and $n$ is the release exponent. The $\mathrm{n}$ values were $0.78-0.92$ with $\mathrm{R}^{2}=0.987-0.996$. Although in the classical Higuchi diffusion model, the release exponent is $0.5,[88]$ deviation of the release exponent between 0-1 is often reported, which can be attributed to the polymer material geometry and anomalous transport mechanism.[87, 88] The release rate constants, ranging $0.4-1.2 \mathrm{~min}^{-1 / 2}$ in our system, are strongly affected by the molecular interactions of the system. Specifically, the attachment of the fluorous tag to the molecules creates the fluorous interactions among the molecules as well as between the molecules and the fluorous side chains of the contact lens polymers. The combination of these two effects greatly slows down the 
release of the molecules from the contact lens matrix.

\section{Conclusion}

In conclusion, we demonstrated that fluorous interactions could be utilized to greatly enhance loading of fluorous-tagged molecules into fluorine-containing delivery systems. The antibioticloaded delivery system exhibited nearly complete growth inhibition of bacterium $P$. aeruginosa in vitro and ex vivo while having no cytotoxicity towards host cells and no effect on the optical quality of the lenses. Furthermore, our results encourage further investigation of the antimicrobial properties and cytotoxicity of fluorous-tagged ciprofloxacin loaded contact lenses and other fluorous-based biomaterial systems in vivo for better understanding of their actions and their potential applications in the clinic.

\section{Acknowledgments}

This work was supported by the National Institutes of Health [EY13175], National Science Foundation [DMR-1508722], the University of Houston GEAR grant and the New Faculty Research Program Award.

\section{References}

[1] D. Ghate, H.F. Edelhauser. Ocular drug delivery. Expert Opin. Drug Deliv. 3 (2006) 275-87.

[2] J.C. Lang. Ocular drug-delivery conventional ocular formulations. Adv. Drug Deliv. Rev. 16 (1995) 39-43.

[3] C.J. White, A. Tieppo, M.E. Byrne. Controlled drug release from contact lenses: a comprehensive review from 1965-present. J. Drug Deliv. Sci. Technol. 21 (2011) 369-384.

[4] D. Dutta, M.D.P. Willcox. Antimicrobial Contact Lenses and Lens Cases: A Review. Eye Contact Lens-Sci. Clin. Pra. 40 (2014) 312-324.

[5] K.H. Hsu, S. Gause, A. Chauhan. Review of ophthalmic drug delivery by contact lenses. J. Drug Deliv. Sci. Technol. 24 (2014) 123-135.

[6] C.M. Phan, L. Subbaraman, L. Jones. Contact lenses for antifungal ocular drug delivery: a review. Expert Opin. Drug Deliv. 11 (2014) 537-546.

[7] J.B. Ciolino, C.H. Dohlman, D.S. Kohane. Contact Lenses for Drug Delivery. Semin. Ophthalmol. 24 (2009) 156-160.

[8] L.C. Bengani, K.H. Hsu, S. Gause, A. Chauhan. Contact lenses as a platform for ocular drug delivery. Expert Opin. Drug Deliv. 10 (2013) 1483-1496.

[9] M. Ruben, R. Watkins. Pilocarpine dispensation for soft hydrophilic contact-lens. Br. J. Ophthalmol. 59 (1975) 455-458.

[10] J.K. Xu, X.S. Li, F.Q. Sun. In vitro and in vivo evaluation of ketotifen fumarate-loaded silicone hydrogel contact lenses for ocular drug delivery. Drug Deliv. 18 (2011) 150-158.

[11] L.C. Winterton, J.M. Lally, K.B. Sentell, L.L. Chapoy. The elution of poly (vinyl alcohol) from a contact lens: The realization of a time release moisturizing agent/artificial tear. J. Biomed. Mater. Res. Part B 80B (2007) 424-432.

[12] M.R. Jain. Drug delivery through soft contact lenses. Br. J. Ophthalmol. 72 (1988) 150-154. 
[13] A. Soluri, A. Hui, L. Jones. Delivery of Ketotifen Fumarate by Commercial Contact Lens Materials. Optom. Vis. Sci. 89 (2012) 1140-1149.

[14] A. Hui, A. Boone, L. Jones. Uptake and release of ciprofloxacin-HCl from conventional and silicone hydrogel contact lens materials. Eye Contact Lens-Sci. Clin. Pra. 34 (2008) 266271.

[15] C.C.S. Karlgard, N.S. Wong, L.W. Jones, C. Moresoli. In vitro uptake and release studies of ocular pharmaceutical agents by silicon-containing and p-HEMA hydrogel contact lens materials. Int. J. Pharm. 257 (2003) 141-151.

[16] J. Kim, A. Chauhan. Dexamethasone transport and ocular delivery from poly(hydroxyethyl methacrylate) gels. Int. J. Pharma. 353 (2008) 205-222.

[17] C.C. Li, A. Chauhan. Ocular transport model for ophthalmic delivery of timolol through pHEMA contact lenses. J. Drug Deliv. Sci. Technol. 17 (2007) 69-79.

[18] C. Alvarez-Lorenzo, H. Hiratani, J.L. Gomez-Amoza, R. Martinez-Pacheco, C. Souto, A. Concheiro. Soft contact lenses capable of sustained delivery of timolol. J. Pharm. Sci. 91 (2002) 2182-2192.

[19] C. Alvarez-Lorenzo, F. Yanez, R. Barreiro-Iglesias, A. Concheiro. Imprinted soft contact lenses as norfloxacin delivery systems. J. Control. Release 113 (2006) 236-244.

[20] C. Alvarez-Lorenzo, F. Yanez, A. Concheiro. Ocular drug delivery from molecularlyimprinted contact lenses. J. Drug Deliv. Sci. Technol. 20 (2010) 237-248.

[21] C.J. White, M.E. Byrne. Molecularly imprinted therapeutic contact lenses. Expert Opin. Drug Deliv. 7 (2010) 765-780.

[22] C.J. White, M.K. McBride, K.M. Pate, A. Tieppo, M.E. Byrne. Extended release of high molecular weight hydroxypropyl methylcellulose from molecularly imprinted, extended wear silicone hydrogel contact lenses. Biomaterials 32 (2011) 5698-5705.

[23] F. Yanez, L. Martikainen, M.E.M. Braga, C. Alvarez-Lorenzo, A. Concheiro, C.M.M. Duarte, M.H. Gil, H.C. de Sousa. Supercritical fluid-assisted preparation of imprinted contact lenses for drug delivery. Acta Biomater. 7 (2011) 1019-1030.

[24] A. Hui, H. Sheardown, L. Jones. Acetic and Acrylic Acid Molecular Imprinted Model Silicone Hydrogel Materials for Ciprofloxacin-HCl Delivery. Materials 5 (2012) 85-107.

[25] A. Tieppo, C.J. White, A.C. Paine, M.L. Voyles, M.K. McBride, M.E. Byrne. Sustained in vivo release from imprinted therapeutic contact lenses. J. Control. Release 157 (2012) 391397.

[26] B. Malaekeh-Nikouei, S.A. Vahabzadeh, S.A. Mohajeri. Preparation of a Molecularly Imprinted Soft Contact Lens as a New Ocular Drug Delivery System for Dorzolamide. Curr. Drug Deliv. 10 (2013) 279-285.

[27] G. Guidi, M. Korogiannaki, H. Sheardown. Modification of Timolol Release From Silicone Hydrogel Model Contact Lens Materials Using Hyaluronic Acid. Eye Contact Lens-Sci. Clin. Pra. 40 (2014) 269-276.

[28] A. Hui, M. Willcox, L. Jones. In Vitro and In Vivo Evaluation of Novel CiprofloxacinReleasing Silicone Hydrogel Contact Lenses. Invest. Ophthalmol. Vis. Sci. 55 (2014) 48964904.

[29] J.B. Ciolino, C.F. Stefanescu, A.E. Ross, B. Salvador-Culla, P. Cortez, E.M. Ford, K.A. Wymbs, S.L. Sprague, D.R. Mascoop, S.S. Rudina, S.A. Trauger, F. Cade, D.S. Kohane. In vivo performance of a drug-eluting contact lens to treat glaucoma for a month. Biomaterials 35 (2014) 432-439. 
[30] F.A. Maulvi, D.H. Lakdawala, A.A. Shaikh, A.R. Desai, H.H. Choksi, R.J. Vaidya, K.M. Ranch, A.R. Koli, B.A. Vyas, D.O. Shah. In vitro and in vivo evaluation of novel implantation technology in hydrogel contact lenses for controlled drug delivery. J. Control. Release 226 (2016) 47-56.

[31] P. Paradiso, V. Chu, L. Santos, A.P. Serro, R. Colaco, B. Saramago. Effect of plasma treatment on the performance of two drug-loaded hydrogel formulations for therapeutic contact lenses. J. Biomed. Mater. Res. Part B 103 (2015) 1059-1068.

[32] K. Hagiwara, T. Hasebe, A. Hotta. Effects of plasma treatments on the controlled drug release from poly(ethylene-co-vinyl acetate). Surf. Coat. Technol. 216 (2013) 318-323.

[33] D. Gulsen, C.C. Li, A. Chauhan. Dispersion of DMPC liposomes in contact lenses for ophthalmic drug delivery. Curr. Eye Res. 30 (2005) 1071-1080.

[34] J.F.R. dos Santos, C. Alvarez-Lorenzo, M. Silva, L. Balsa, J. Couceiro, J.J. TorresLabandeira, A. Concheiro. Soft contact lenses functionalized with pendant cyclodextrins for controlled drug delivery. Biomaterials 30 (2009) 1348-1355.

[35] R. Garhwal, S.F. Shady, E.J. Ellis, J.Y. Ellis, C.D. Leahy, S.P. McCarthy, K.S. Crawford, P. Gaines. Sustained Ocular Delivery of Ciprofloxacin Using Nanospheres and Conventional Contact Lens Materials. Invest. Ophthalmol. Vis. Sci. 53 (2012) 1341-1352.

[36] X.Y. Yuan, D.C. Marcano, C.S. Shin, X. Hua, L.C. Isenhart, S.C. Pflugfelder, G. Acharya. Ocular Drug Delivery Nanowafer with Enhanced Therapeutic Efficacy. ACS Nano 9 (2015) 1749-1758.

[37] D.M. Robertson. The Effects of Silicone Hydrogel Lens Wear on the Corneal Epithelium and Risk for Microbial Keratitis. Eye Contact Lens-Sci. Clin. Pra. 39 (2013) 67-72.

[38] A. Saini, C.J. Rapuano, P.R. Laibson, E.J. Cohen, K.M. Hammersmith. Episodes of Microbial Keratitis With Therapeutic Silicone Hydrogel Bandage Soft Contact Lenses. Eye Contact Lens-Sci. Clin. Pra. 39 (2013) 324-328.

[39] J.P. Shovlin. Ocular surface health with contact lens wear. Cont. Lens Anterior Eye 36 (2013) S14-S21.

[40] N. Konda, M. Willcox. Review of Inflammation and Infection in Contact Lens Wears: Risk Factors and Association with Single Nucleotide Polymorphisms. J. Ocular Bio. 1 (2013) 9.

[41] L. Szczotka-Flynn, M. Diaz. Risk of corneal inflammatory events with silicone hydrogel and low Dk hydrogel extended contact lens wear: A meta-analysis. Optom. Vis. Sci. 84 (2007) 247-256.

[42] F. Stapleton, S. Stretton, E. Papas, C. Skotnitsky, D.F. Sweeney. Silicone hydrogel contact lenses and the ocular surface. Ocul. Surf. 4 (2006) 24-43.

[43] N.M. Farandos, A.K. Yetisen, M.J. Monteiro, C.R. Lowe, S.H. Yun. Contact Lens Sensors in Ocular Diagnostics. Adv. Healthc. Mater. 4 (2015) 792-810.

[44] K.Y. Chana, P. Cho, M. Boost. Microbial adherence to cosmetic contact lenses. Cont. Lens Anterior Eye 37 (2014) 267-272.

[45] M. Ray, D.K. Lim. Rare Polymicrobial Keratitis Involving Chryseobacterium meningosepticum and Delftia acidovorans in a Cosmetic Contact Lens Wearer. Eye Contact Lens-Sci. Clin. Pra. 39 (2013) 192-193.

[46] H. Yao, Y. Liao, A.R. Lingley, A. Afanasiev, I. Lahdesmaki, B.P. Otis, B.A. Parviz. A contact lens with integrated telecommunication circuit and sensors for wireless and continuous tear glucose monitoring. J. Micromech. Microeng. 22 (2012) 10.

[47] S. Singh, D. Satani, A. Patel, R. Vhankade. Colored Cosmetic Contact Lenses: An Unsafe Trend in the Younger Generation. Cornea 31 (2012) 777-779. 
[48] A. Sauer, T. Bourcier, R. French Study Grp Contact Lenses. Microbial keratitis as a foreseeable complication of cosmetic contact lenses: a prospective study. Acta Ophthalmol. 89 (2011) E439-E442.

[49] M.X. Chu, T. Shirai, D. Takahashi, T. Arakawa, H. Kudo, K. Sano, S. Sawada, K. Yano, Y. Iwasaki, K. Akiyoshi, M. Mochizuki, K. Mitsubayashi. Biomedical soft contact-lens sensor for in situ ocular biomonitoring of tear contents. Biomed. Microdevices 13 (2011) 603-611.

[50] H.F. Yao, A.J. Shum, M. Cowan, I. Lahdesmaki, B.A. Parviz. A contact lens with embedded sensor for monitoring tear glucose level. Biosens. Bioelectron. 26 (2011) 32903296.

[51] A. Malik, C. Claoue. Transport and interaction of cosmetic product material within the ocular surface: Beauty and the beastly symptoms of toxic tears. Cont. Lens Anterior Eye 35 (2012) 247-259.

[52] D. Dutta, J. Ozkan, M.D.P. Willcox. Biocompatibility of Antimicrobial Melimine Lenses: Rabbit and Human Studies. Optom. Vis. Sci. 91 (2014) 570-581.

[53] I.T. Horvath, J. Rabai. Facile catalyst separation without water - fluorous biphase hydroformylation of olefins. Science 266 (1994) 72-75.

[54] R. Berger, G. Resnati, P. Metrangolo, E. Weber, J. Hulliger. Organic fluorine compounds: a great opportunity for enhanced materials properties. Chem. Soc. Rev. 40 (2011) 3496-3508.

[55] T. Hayama, H. Yoshida, M. Yamaguchi, H. Nohta. Fluorous affinity-based separation techniques for the analysis of biogenic and related molecules. J. Pharm. Biomed. Anal. 101 (2014) 151-160.

[56] D. Anton. Surface-fluorinated coatings. Adv. Mater. 10 (1998) 1197-1205.

[57] H.M. Hugel, N. Jackson. Special Feature Organo-Fluorine Chemical Science. Appl. Sci.Basel 2 (2012) 558-565.

[58] L. McKeen, Fluorinated Coatings and Finishes Handbook, William Andrew 2007.

[59] E.T. Ahrens, R. Flores, H.Y. Xu, P.A. Morel. In vivo imaging platform for tracking immunotherapeutic cells. Nat. Biotechnol. 23 (2005) 983-987.

[60] G.P. Biro, P. Blais. Perfluorocarbon blood substitutes. Crit. Rev. Oncol. Hematol. 6 (1987) 311-374.

[61] C.I. Castro, J.C. Briceno. Perfluorocarbon-Based Oxygen Carriers: Review of Products and Trials. Artif. Organs 34 (2010) 622-634.

[62] J.M. Janjic, E.T. Ahrens. Fluorine-containing nanoemulsions for MRI cell tracking. Wiley Interdiscip. Rev.-Nanomed. Nanobiotechnol. 1 (2009) 492-501.

[63] N. Rapoport. Phase-shift, stimuli-responsive perfluorocarbon nanodroplets for drug delivery to cancer. Wiley Interdiscip. Rev.-Nanomed. Nanobiotechnol. 4 (2012) 492-510.

[64] N. Reznik, R. Williams, P.N. Burns. Investigation of vaporized submicron perfluorocarbon droplets as an ultrasound contrast agent. Ultrasound Med. Biol. 37 (2011) 1271-1279.

[65] C.M. Santos, A. Kumar, S.S. Kolar, R. Contreras-Caceres, A. McDermott, C.Z. Cai. Immobilization of Antimicrobial Peptide IG-25 onto Fluoropolymers via Fluorous Interactions and Click Chemistry. ACS Appl. Mater. Interfaces 5 (2013) 12789-12793.

[66] D.M. Robertson, L. Li, S. Fisher, V.P. Pearce, J.W. Shay, W.E. Wright, H.D. Cavanagh, J.V. Jester. Characterization of growth and differentiation in a telomerase-immortalized human corneal epithelial cell line. Invest. Ophthalmol. Vis. Sci. 46 (2005) 470-478.

[67] C.C.S. Karlgard, D.K. Sarkar, L.W. Jones, C. Moresoli, K.T. Leung. Drying methods for XPS analysis of PureVision (TM), Focus (R) Night \& Day \&(TM) and conventional hydrogel contact lenses. Appl. Surf. Sci. 230 (2004) 106-114. 
[68] A. Tieppo, A.C. Boggs, P. Pourjavad, M.E. Byrne. Analysis of release kinetics of ocular therapeutics from drug releasing contact lenses: Best methods and practices to advance the field. Cont. Lens Anterior Eye 37 (2014) 305-313.

[69] N. Eter, M. Gobbels. A new technique for tear film fluorophotometry. Br. J. Ophthalmol. 86 (2002) 616-619.

[70] J.R. Occhipinti, M.A. Mosier, J. Lamotte, G.T. Monji. Fluorophotometric measurement of human tear turnover rate. Curr. Eye Res. 7 (1988) 995-1000.

[71] W.R.S. Webber, D.P. Jones. Continuous fluorophotometric method of measuring tear turnover rate in humans and analysis of factors affecting accuracy. Med. Biol. Eng. Comput. 24 (1986) 386-392.

[72] W.R.S. Webber, D.P. Jones, P. Wright. Fluorophotometric measurements of tear turnover rate in normal healthy persons - evidence for a circadian rhythm. Trans. Ophthalmol. Soc. U.K. 1 (1987) 615-620.

[73] S.L. Pendland, M.M. Neuhauser, K.W. Garey, J.L. Prause, R. Jung. Comparative killing rates of gatifloxacin and ciprofloxacin against 14 clinical isolates: impact of bacterial strain and antibiotic concentration. Diagn. Microbiol. Infect. Dis. 44 (2002) 59-61.

[74] T.Y. Tsai, T.C. Chen, I.J. Wang, C.Y. Yeh, M.J. Su, R.H. Chen, T.H. Tsai, F.R. Hu. The Effect of Resveratrol on Protecting Corneal Epithelial Cells from Cytotoxicity Caused by Moxifloxacin and Benzalkonium Chloride. Invest. Ophthalmol. Vis. Sci. 56 (2015) 15751584.

[75] N. Onizuka, M. Uematsu, M. Kusano, H. Sasaki, K. Suzuma, T. Kitaoka. Influence of Different Additives and Their Concentrations on Corneal Toxicity and Antimicrobial Effect of Benzalkonium Chloride. Cornea 33 (2014) 521-526.

[76] A. Iwasawa, M. Ayaki, Y. Niwano. Cell viability score (CVS) as a good indicator of critical concentration of benzalkonium chloride for toxicity in cultured ocular surface cell lines. Regul. Toxicol. Pharmacol. 66 (2013) 177-183.

[77] P. Tankam, J. Won, C. Canavesi, I. Cox, J.P. Rolland. Optical Assessment of Soft Contact Lens Edge-Thickness. Optom. Vis. Sci. 93 (2016) 987-996.

[78] D. Jaishankar, J.S. Buhrman, T. Valyi-Nagy, R.A. Gemeinhart, D. Shukla. Extended Release of an Anti-Heparan Sulfate Peptide From a Contact Lens Suppresses Corneal Herpes Simplex Virus-1 Infection. Invest. Ophthalmol. Vis. Sci. 57 (2016) 169-180.

[79] P.B.J. Vermeltfoort, T.G. van Kooten, G.M. Bruinsma, A.M.M. Hooymans, H.C. van der Mei, H.J. Busscher. Bacterial transmission from contact lenses to porcine corneas: An ex vivo study. Invest. Ophthalmol. Vis. Sci. 46 (2005) 2042-2046.

[80] C.J. Pino, F.R. Haselton, M.S. Chang. Seeding of corneal wounds by epithelial cell transfer from micropatterned PDMS contact lenses. Cell Transplant. 14 (2005) 565-571.

[81] M. Leonardi, P. Leuenberger, D. Bertrand, A. Bertsch, P. Renaud. First steps toward noninvasive intraocular pressure monitoring with a sensing contact lens. Invest. Ophthalmol. Vis. Sci. 45 (2004) 3113-3117.

[82] I. Iguchi, K. Kamiyama, M. Imamichi, T. Ohashi, J.C. He, X.G. Wang, J. Imanishi. Influence of dynamic contact of hard contact lens materials on corneal epithelial cells examined by rose bengal staining. Curr. Eye Res. 15 (1996) 647-652.

[83] Y.G. He, J.P. McCulley, H. Alizadeh, M. Pidherney, J. Mellon, J.E. Ubelaker, G.L. Stewart, R.E. Silvany, J.Y. Niederkorn. A pig model of acanthamoeba keratitis - transmission via contaminated contact lenses. Invest. Ophthalmol. Vis. Sci. 33 (1992) 126-133. 
[84] J.D. Bartlett, S.D. Jaanus, Clinical Ocular Pharmacology, 5th ed., Butterworth-Heinemann, St. Louis, MO, USA, 2008.

[85] H. Omorodion, B. Twamley, J.A. Platts, R.J. Baker. Further Evidence on the Importance of Fluorous-Fluorous Interactions in Supramolecular Chemistry: A Combined Structural and Computational Study. Cryst. Growth Des. 15 (2015) 2835-2841.

[86] H.J. Lee, A.C. Jamison, T.R. Lee. Surface Dipoles: A Growing Body of Evidence Supports Their Impact and Importance. Accounts Chem. Res. 48 (2015) 3007-3015.

[87] N.A. Peppas. Analysis of fickian and non-fickian drug release from polymers. Pharm. Acta Helv. 60 (1985) 110-111.

[88] J. Siepmann, N.A. Peppas. Higuchi equation: Derivation, applications, use and misuse. Int. J. Pharm. 418 (2011) 6-12. 